\title{
Ectopic Pancreatic Tissue at the Tip of Meckel's Diverticulum
}

\author{
Monalisa Dash, K.P.A. Chandrasekhar \\ Department of Pathology, SVS Medical College, Mahabubngar, Telangana-509001, India.
}

\section{Corresponding Author: \\ Dr. Monalisa Dash}

Email: monalisha89@gmail.com

This is an Open Access article distributed under the terms of the Creative Commons Attribution License (creativecommons.org/ licenses/by/3.0).

Received

Accepted

Published

October 10, 2016

December 14, 2016

January 20, 2017

\begin{abstract}
Background: Ectopic pancreas is defined as the presence of normally organized pancreatic tissue lying outside its normal location without any anatomical and vascular continuity with the proper pancreas. It is frequently found in stomach, duodenum, gall bladder, liver, spleen etc. and very rarely found associated with the Meckel's diverticulum. The reported frequency of ectopic pancreatic tissue ranges between $0.5-14 \%$. A combination of Meckel's diverticulum with ectopic pancreatic tissue is extremely rare. Case Report: We report a case of a 14-year-old male with abdominal pain, loss of appetite and vomiting, later found histologically ectopic pancreatic tissue in a Meckel's diverticulum. Conclusion: Definitive preoperative diagnosis is challenging for such rare entities and requires pathological examination of the resected specimen.
\end{abstract}

Keywords: Abdominal Pain, Liver, Meckel Diverticulum, Pancreas, Vomiting.

\section{Introduction}

Meckel's diverticulum, a true congenital diverticulum, is a slight bulge in the small intestine present at birth and a vestigial remnant of the omphalomesenteric duct (also called the vitelline duct or yolk stalk) [1]. Meckel's diverticulum was first explained by Wilhelm Fabricius Hildanus, a German surgeon in 1598 and later named after Johann Friedrich Meckel, who described the embryological origin of this type of diverticulum in 1809 [2,3]. Meckel's diverticulum occurs in about $2 \%$ of the population [4]. Prevalence in males is 3-5 times higher than in females [5]. Patients with Meckel's are usually asymptomatic and the diverticulae are invariably discovered incidentally at autopsy, laparotomy or laparoscopy. Complications from Meckel's usually arise from its underlying mucosa: $50 \%$ of which are ectopic mucosae such as gastric mucosa (18\%-40\%), pancreatic tissue (5-16\%) and less commonly duodenal, colonic and biliary tissue [6]. We report a case of Meckel's diverticulum with ectopic pancreatic tissue which is considered to be rare.

\section{Case Report}

A 14-year-old boy presented with complaints of with pain abdomen and vomiting since 3 days. He also had similar episodes of pain earlier with loss of appetite and weight loss. There was no relevant past history. Cause of vomiting was under evaluation. Vomiting was so severe that he required intravenous fluid therapy. Initial investigations revealed a hemoglobin level of $10.2 \mathrm{~g} / \mathrm{dL}$. Biochemical assessments of liver and renal functions were normal. Platelet count was slightly decreased. Ultrasonography of abdomen reveals tubular defects giving clue towards intestinal lesions probably Meckel's diverticulum. He was offered abdominal exploration due to suspected diagnosis of intestinal obstruction. During surgery, Meckel's diverticulum was found and consequently, diverticulectomy was carried out and was sampled for histopathological examination. Post-operative period was uneventful and the patient was discharged from the hospital after 7 days. 
Gross examination of the specimen revealed a gangrenous segment of intestine measuring 42x5 cms attached with the Meckel's diverticulum at one end measuring $5 \times 2 \mathrm{cms}$. Surface was brown to black in colour with areas of hemorrhages [Fig.1]. Cut section showed intestinal mucosa along with whitish patches. Sections were given from the resected ends and from the whitish area along with few random bits. Multiple histological sections revealed the structure of intestine along with normal mucosal glands and showed presence of ectopic pancreatic tissue in the mucosal layer, transmural infiltration of lymphocytes, pancreatic tissue consisting of acini and focal hemorrhages [Fig.2].

\section{Discussion}

We present a case of Meckel's diverticulum with presence of ectopic pancreatic tissue in 14 years old boy who was asymptomatic for 4 years and came to hospital with complaints of severe vomiting and abdominal pain. Pre-operative diagnosis was little difficult. Intra-operatively surgeons diagnosed it as Meckel's diverticulum and they sent biopsy for histopathological examination. Histopathological examination of the specimen revealed presence of ectopic pancreatic tissue. Histologically there is presence of acini and that comes under type one ectopic pancreas.

Heterotopic pancreatic tissue itself is uncommon, with reported frequency between 0.5 to $13.7 \%$ [7]. Heterotopic pancreases were first described by Shultz in 1727. It is the presence of pancreatic tissue which lacks anatomical and vascular continuity with the pancreas. Similar to Meckel's diverticulum, ectopic pancreatic tissues are usually asymptomatic and are found incidentally. Histologically, heterotopic pancreas is of 4 types: those comprising (i) ducts only (canalicular heterotopia), (ii) acinar cells only (exocrine heterotopia), and (iii) islet cells only (endocrine heterotopia) iv) all cell types (total heterotopia). The presence of ectopic tissues

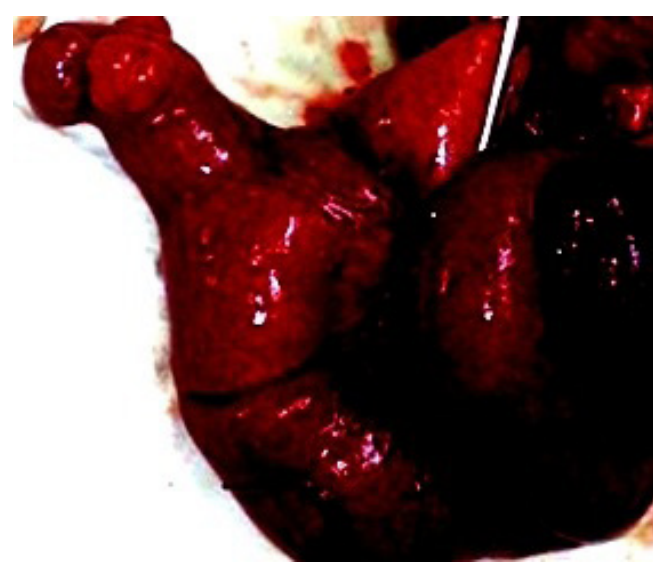

Fig.1: Intestinal segment measuring $42 \mathrm{cms}$ in length with attached Meckel's diverticulum at one end measuring $5 \times 2$ cms showing gangrenous changes.

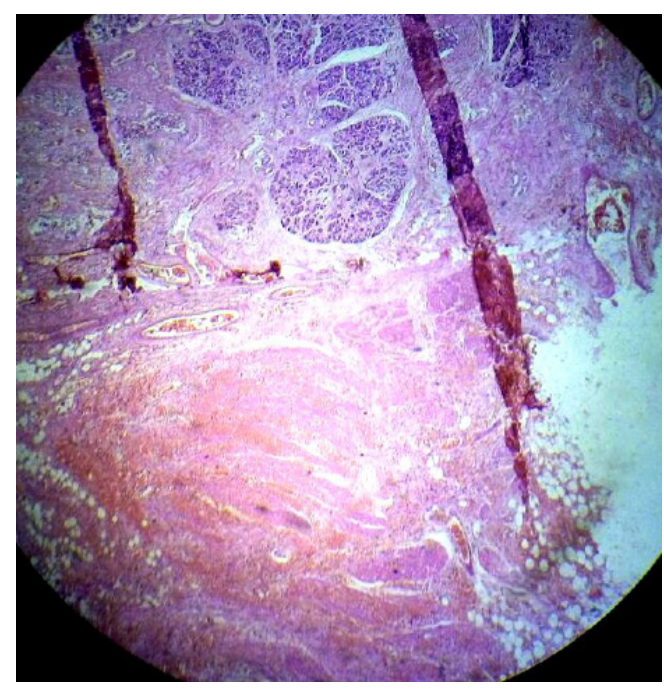

Fig.2: $H \& E$ sections shows structure of intestine along with pancreatic acini.

within Meckel's diverticulum has been noted since the early 1900s, and historically, many hypothesis have been proposed to explain their presence $[8,9]$. The now widely-accepted theory proposes that the pluripotent cells that once lined the omphalomesenteric duct are responsible for giving rise to the various ectopic tissues within the Meckel's diverticulum [10-12]. This theory, however, fails to explain the strong preponderance for finding ectopic gastric or ectopic pancreatic tissues with Meckel's diverticulum. Case reports 
of less common ectopic tissues, such as colonic, duodenal, jejunal, hepatic, and endometrial, are very few in numbers. It is unknown why the pluripotent cells of the omphalomesenteric duct would more commonly differentiate into one type of tissue over another. It has been proposed that ectopic pancreatic tissue may be misplaced tissue from migration and fusion of the ventral and dorsal pancreatic buds during embryology [13]. It has also been suggested that improper molecular signalling throughout the gastrointestinal tract with loss of the sonic hedgehog gene might be responsible ectopic pancreatic tissue [14]. The differential diagnosis of heterotopic pancreas include gastrointestinal stromal tumor, adenomyoma, leiomyoma, gastrointestinal autonomic nerve tumor, and lymphoma and carcinoid tumor [15].

\section{Conclusion}

Meckel's diverticulum is the most common anomaly of the gastrointestinal tract whereas Meckel's diverticulum with ectopic pancreatic tissue is a rare clinical entity. Painless bleeding is one of the complications seen in cases of Meckel's diverticulum with ectopic pancreatic tissue, but only abdominal pain with vomiting can also be a presenting symptom. Definitive preoperative diagnosis still remains challenging. The definitive diagnosis is confirmed by pathological examination of the resected specimen.

Contributors: MD: Histopathology and writing manuscript; KPAC: Histopathology and critical review of manuscript. MD will act as guarantor. Both authors approved the final version of manuscript.

Funding: None; Competing interests: None stated.

\section{References}

1. Elsayes KM, Menias CO, Harvin HJ, Francis IR. Imaging manifestations of Meckel's diverticulum. AJR
Am J Roentgenol. 2007;189(1):81-88.

2. Meckel JF. Über die Divertikel am Darmkanal. Archivfür die Physiologie, Halle, 1809;9:421-453.

3. Haber JJ. Meckel's diverticulum: review of literature and analytical study of 23 cases with particular emphasis on bowel obstruction. Am J Surg. 1947;73:468-485.

4. Robbins SL, Kumar V, Cotran RS. Robbins and Cotran pathologic basis of disease $\left(8^{\text {th }}\right.$ ed.). Philadelphia, PA: Saunders/Elsevier.

5. Moore KL, Persaud TVN, Torchia, MG. The developing human: Clinically oriented embryology ( $9^{\text {th }}$ ed.). Philadelphia: Elsevier/Saunders, 2013.

6. Levy AD, Hobbs CM. Meckel diverticulum: radiologic features with pathologic correlations. Radiographics. 2004;24:565-587.

7. Dolan RV, Remine WH, Dockerty MB. The fate of heterotopic pancreatic tissue - A study of 212 cases. Arch Surg. 1974; 109:762-765.

8. Soderlund S. Meckel's diverticulum. A clinical and histologic study. Acta Chir Scand Suppl. 1959;248(Suppl):1-233.

9. Bigelow R, Clark DE. Heterotopic pancreatic tissue and gastric mucosa in Meckel's diverticulum. Arch Surg. 1950;60:157-163.

10. Sharma RK, Jain VK. Emergency surgery for Meckel's diverticulum. World J Emerg Surg. 2008;3:27.

11. Varcoe RL, Wong SW, Taylor CF, Newstead GL. Diverticulectomy is inadequate treatment for short Meckel's diverticulum with heterotopic mucosa. ANZ J Surg. 2004;74:869-872.

12. Mukai M, Takamatsu H, Noguchi H, Fukushige T, Tahara H, Kaji T. Does the external appearance of a Meckel's diverticulum assist in choice of the laparoscopic procedure? Pediatr Surg Int. 2002;18:231-233.

13. Bromberg SH, CamiloNeto C, Borges AF, Franco MI, França LC, Yamaguchi N. Pancreatic heterotopias: Clinicopathological analysis of 18 patients. Rev Col Bras Cir. 2010;37:413-419.

14. Baysoy G, Balamtekin N, Uslu N, Karavelioðlu A, Talim B, Ozen H. Double heterotopic pancreas and Meckel's diverticulum in a child: Do they have a common origin? Turk J Pediatr. 2010;52:336-338.

15. Riyaz A, Cohen H. Ectopic pancreas presenting as a submucosal gastric antral tumor that was cystic on EUS. Gastrointest Endosc. 2001;53(6):675-677. 